\title{
Nutrient Loss from a Tea Plantation Area in Japan
}

\author{
Toshiro YAMADA*, Takanobu INOUE**, Koji TSUSHIMA***, Masahiro NAGAI****, \\ Yoshiaki KISO***** \\ * Department of Water Supply Engineering, National Institute of Public Health, Saitama \\ 351-0197, JAPAN \\ ** Department of Architecture and Civil Engineering, Toyohashi University of Technology, Aichi \\ 441-8580, JAPAN \\ ***Department of Bioenvironmental and Agricultural Engineering, College of Bioresource \\ Science, Nihon University, Kanagawa 252-8510 JAPAN \\ **** Division of Human Environment, University of Human Environment, Aichi 444-3505, \\ JAPAN \\ ***** Department of Ecological Engineering, Toyohashi University of Technology, Aichi \\ 441-8580, JAPAN
}

\begin{abstract}
A great amount of fertilizer is applied to tea plantation area to improve the quality of the product in Japan. Field surveys on water quality of a small river whose watershed includes tea plantation fields and questionnaire survey to the owners in the area were carried out to make clear the runoff characteristics of nutrients, both nitrogen and phosphorus, from a small watershed including the tea plantation area, and to estimate the annual budget of the nutrients. The concentrations of nitrate and phosphate in the stream water in dry period through the tea field were up to $8.09 \mathrm{mgN} / \mathrm{L}$ and $0.065 \mathrm{mgP} / \mathrm{L}$ respectively, which were more than 10 times higher than those in the upstream water which run through the forest. Seasonal variations of the N concentrations and $\mathrm{P}$ concentrations in dry periods were observed which were independent from the timing of fertilizer application. During a storm event, the concentrations of phosphate, particulate phosphorus and particulate nitrogen increased while those of nitrate decreased. Large amount of nitrogen fertilizer, $620 \mathrm{kgN} / \mathrm{ha} /$ year, was applied to the tea plantation area in a year and it was estimated that only $12 \%$ of the nitrogen input was recovered as harvest product and $86 \%$ of the input was discharged downstream through the river. $55 \mathrm{kgP} / \mathrm{ha} /$ year of phosphorus fertilizer was applied to the area in a year, and it was estimated that $10 \%$ of the phosphorus input was recovered and $38 \%$ discharged.
\end{abstract}

Keywords: nutrients, loading, nitrogen, phosphorus, tea plantation area.

\section{INTRODUCTION}

Nutrient loading from agricultural area has been focused on for progress on improvement of water quality in closed water body such as lakes and enclosed coastal seas in Japan as well as other countries. Almost $74 \%$ of annual amount of nutrient fertilizer applied to the whole cultivated lands in Japan is applied to the dry fields, which is account for approximately $63 \%$ of the cultivated lands of the country (Shiratani et al., 2004). This indicates that the impact of the runoff loading from dry field should be clarified to conserve the water environment downstream. A great amount of fertilizer is applied to tea fields to improve the quality of the product such as taste of tea, and high nitrate concentrations as much as about $50 \mathrm{mg} / \mathrm{L}$ in river and reservoir water were reported in a tea field in Japan (Nakasone et al., 2003). It have been also reported that the high concentrations of nitrogen of river water running through a tea plantation area were observed (Yamamoto et al., 2005). In previous studies, nutrient loss from tea plantation area was reported (Hasegawa et al., 1985, Matsuo et al., 2000, Takeda et al.,

Address correspondence to Toshiro Yamada, Department of Water Supply Engineering, National Institute of Public Health, Email: t-yamada@niph.go.jp

Received January 6, 2009, Accepted November 17, 2009. 
2002), although no evaluation in the storm periods was included in these studies. Impact of nutrient loss during storm event should be taken into account to evaluate its annual loading from non-point sources including tea plantation area. The objectives of this study are to make clear the impact of the fertilizer application in a small watershed including the tea plantation area on the river water quality and to estimate annual balance of nutrients, nitrogen and phosphorus, in the area using the data including survey results in a storm event.

\section{MATERIALS AND METHODS}

\section{Study Site}

Site of this study is located in central Japan. Annual mean air temperature and annual precipitation at the observing station near the study site were 17.2 degrees C and 1797 $\mathrm{mm}$, respectively, reported by the Japan meteorological Agency in 2004. The study site is famous for the production of high-quality green tea leaves. The tea plantation in this area started more than 60 years ago. The total area of watershed at the sampling point is 41.5ha, including the area of $4.5 \mathrm{ha}$ of tea fields. The major bedrock at the area is granite. The watershed of the upstream is forest and no wastewater drainage is linked to the river. Vegetative stage of tea trees is normally between March and October in this area. According to a guideline for farmers on annual plan of tea plantation in this area, application of basal fertilizer for tea growth in spring is normally conducted in the periods between middle February and the end of March. Additional fertilizer in summer and fertilizer for autumn growth are applied in early June and in the period between August and September, respectively. Application of organic fertilizer such as rapeseed meal is basically recommended, and annual nutrient application amounts of fertilizer are $66 \mathrm{kgN} / \mathrm{ha}$ as nitrogen and $25 \mathrm{kgP} / \mathrm{ha}$ as phosphorus in this area.

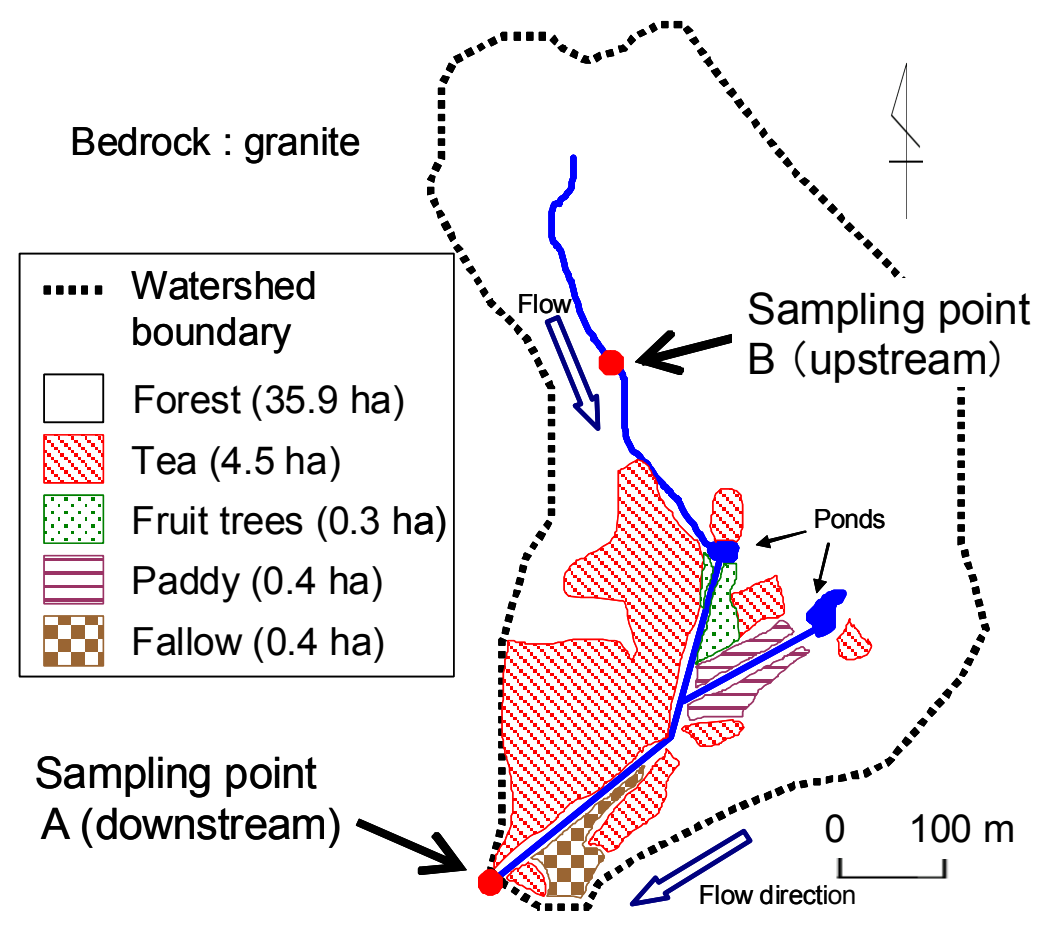

Fig.1 Map of the study site 


\section{Sampling and analysis}

The surveys were carried out monthly from April to December in 2003 as a preliminary survey, and weekly from April to October in 2005. Water samples were collected from a small river which flows through a tea field at sampling point A (Fig. 1). A survey during a heavy storm event was also carried out in October 2004. In the period, water samples were collected every 30 minutes. Samples of upstream at sampling point B were also collected for the analysis of nutrient concentrations as for the background. The flow rate at sampling point A was measured with an electromagnetic current meter at field investigation. Water levels and precipitation were observed automatically at 10 minute interval using an on-site monitoring system at the sampling point downstream in 2004 and 2005. Continuous at 10-min intervals water discharge data at the downstream site were calculated using the relationship between the measured discharges with the current meter and the automatically measured water levels. Electric conductivity (EC) and pH were measured on site. Water samples transported to the laboratory were filtered through a pre-combusted Whatman GF/F glass-fibre filter (mean pore size: $0.7 \mu \mathrm{m}$ ) for the other analyses including concentrations of dissolved nitrogen (DN), dissolved phosphorus (DP), nitrate, nitrite, ammonium, phosphate and other major ions. Those analyses were performed in accordance with the official standard methods. Total nitrogen (TN) and total phosphorus (TP) were analyzed with unfiltered water samples. Concentrations of particulate nitrogen $(\mathrm{PN})$ and particulate phosphorus (PP) were calculated with the difference between $\mathrm{TN}$ and $\mathrm{DN}$ and those between TP and DP, respectively.

\section{Questionnaire surveys}

Questionnaire surveys to the farmers in the tea plantation area were made in 2004 and 2005 to investigate the amount of fertilizer application in 2003 and 2005, respectively, to know the annual fertilizer amount as nutrients input. Type, amount and application timing of fertilizer that used through the year as well as nutrient contents of the fertilizers were asked by the questionnaire survey to all owners. Monthly nutrient inputs were calculated by the monthly amount of fertilizers and their content rates of nutrients.

\section{RESULTS AND DISCUSSION}

\section{Water quality and seasonal variation of the nutrient concentrations}

The mean values of the concentrations of major ions and those of nutrients in the observation period, between April and December in 2003 and between April and October in 2005, are shown in Table 1. Higher alkalinity and higher concentrations of sulfate ion, potassium ion, magnesium ion and calcium ion at sampling point $\mathrm{A}$ than those at B show that the tea plantation affects much the river water quality. The mean concentrations of nitrate and phosphate in the stream water through the tea field were $8.09 \mathrm{mgN} / \mathrm{L}$ and $0.065 \mathrm{mgP} / \mathrm{L}$ respectively, which were more than 10 times higher than those in the upstream water which run through the forest. 
Table 1 - Mean concentrations and coefficients of variance at the sampling point and the upstream in the period between April and December in 2003, and in the period between April and October in 2005.

\begin{tabular}{|c|c|c|c|c|c|c|c|c|c|c|c|c|c|c|c|}
\hline & \multicolumn{3}{|c|}{$\begin{array}{c}\text { Sampling point } \mathrm{A} \\
\text { Downstream }\end{array}$} & \multicolumn{3}{|c|}{$\begin{array}{c}\text { Sampling point B } \\
\text { Upstream }\end{array}$} & & & \multicolumn{3}{|c|}{$\begin{array}{c}\text { Sampling point } A \\
\text { Downstream }\end{array}$} & \multicolumn{3}{|c|}{$\begin{array}{c}\text { Sampling point B } \\
\text { Upstream }\end{array}$} \\
\hline & & Mean & $\mathrm{CV}^{*}$ & $\mathrm{n}^{\star \star *}$ & Mean & $\mathrm{CV}^{*}$ & $\mathrm{n}^{\star * *}$ & & & Mean & $\mathrm{CV}^{*}$ & $\mathrm{n}^{\star *}$ & Mean & $\mathrm{CV}^{*}$ & $\mathrm{n}^{\star \star *}$ \\
\hline $\mathrm{pH}$ & & 6.9 & 0.05 & 32 & 6.1 & 0.03 & 18 & TN & $(\mathrm{mg} / \mathrm{l})$ & 8.09 & 0.28 & 40 & 0.78 & 0.76 & 19 \\
\hline E.C. & $(\mathrm{mS} / \mathrm{m})$ & 17.6 & 0.11 & 23 & 5.5 & 0.11 & 25 & DN & $(\mathrm{mg} / \mathrm{l})$ & 7.83 & 0.27 & 40 & 0.72 & 0.80 & 26 \\
\hline SS & $(\mathrm{mg} / \mathrm{l})$ & 4.1 & 1.3 & 40 & 1.4 & 1.4 & 25 & PN & $(\mathrm{mg} / \mathrm{l})$ & 0.28 & 1.5 & 40 & 0.07 & 2.1 & 19 \\
\hline Alk. & $(\mathrm{meq} / \mathrm{l})$ & 0.24 & 0.25 & 23 & 0.08 & 0.41 & 18 & $\mathrm{NO}_{3}-\mathrm{N}$ & $(\mathrm{mg} / \mathrm{l})$ & 7.47 & 0.26 & 40 & 0.76 & 0.78 & 26 \\
\hline $\mathrm{Cl}^{-}$ & $(\mathrm{mg} / \mathrm{l})$ & 9.7 & 0.08 & 40 & 10.1 & 0.07 & 26 & $\mathrm{NO}_{2}-\mathrm{N}$ & $(\mathrm{mg} / \mathrm{l})$ & 0.008 & 4.3 & 40 & (N.D.) & & 26 \\
\hline $\mathrm{SO}_{4}{ }^{2-}$ & $(\mathrm{mg} / \mathrm{l})$ & 30.4 & 0.12 & 40 & 4.9 & 0.06 & 26 & $\mathrm{NH}_{4}-\mathrm{N}$ & $(\mathrm{mg} / \mathrm{l})$ & 0.010 & 2.4 & 40 & (N.D.) & & 26 \\
\hline $\mathrm{Na}^{+}$ & $(\mathrm{mg} / \mathrm{l})$ & 7.2 & 0.07 & 40 & 6.5 & 0.10 & 26 & TP & $(\mathrm{mg} / \mathrm{l})$ & 0.065 & 0.74 & 40 & 0.003 & 0.86 & 18 \\
\hline $\mathrm{K}^{+}$ & $(\mathrm{mg} / \mathrm{l})$ & 5.9 & 0.22 & 40 & 0.8 & 0.27 & 26 & DP & $(\mathrm{mg} / \mathrm{l})$ & 0.040 & 1.2 & 40 & 0.003 & 0.80 & 26 \\
\hline $\mathrm{Mg}^{2+}$ & $(\mathrm{mg} / \mathrm{l})$ & 5.9 & 0.17 & 40 & 1.7 & 0.17 & 26 & PP & $(\mathrm{mg} / \mathrm{l})$ & 0.026 & 0.95 & 40 & 0.000 & 1.7 & 18 \\
\hline $\mathrm{Ca}^{2+}$ & $(\mathrm{mg} / \mathrm{l})$ & 13.2 & 0.19 & 40 & 1.4 & 0.27 & 26 & $\mathrm{PO}_{4}-\mathrm{P}$ & $(\mathrm{mg} / \mathrm{l})$ & 0.033 & 1.1 & 40 & 0.001 & 1.9 & 26 \\
\hline
\end{tabular}

Fig. 2 shows the monthly specific amount of application of nitrogen fertilizer calculated by the results of the questionnaire survey and the temporal variations of the concentarations of $\mathrm{TN}$ in the river water. Total application amounts of nitrogen and phosphorus in this area (4.5ha) in 2003 were $2830 \mathrm{kgN}$ and $250 \mathrm{kgP}$, respectively. In this tea plantation area, fertilizer was mainly applied in two seasons, which are early spring during February and March for basal fertilization and summer during August and September for additional fertilization. In the early spring of $2003,46 \%$ and $47 \%$ of annual amount of nitrogen and phosphorus were applied, respectively, while $37 \%$ and $38 \%$ were put in the summer. This pattern of the fertilizer application in the year is typical in this region. As shown in Fig. 2, trend that the TN concentrations increase in May and June and decrease in September to November was observed while almost of all nitroigen fertilizer was applied intensively in February and March and August and September. Fig. 3 shows the monthly specific amount of phosphorus fertilizer and the variations of the concentrations of TP. The trend of TP concentrations in the river was also different from those of the application. It is suggested that water quality in the tea plantation area may not affect directly and immediately by fertilizer application. However, it could also be suggested that nutrient concentrations increase in 3 or 4 months after fertilizer application. 


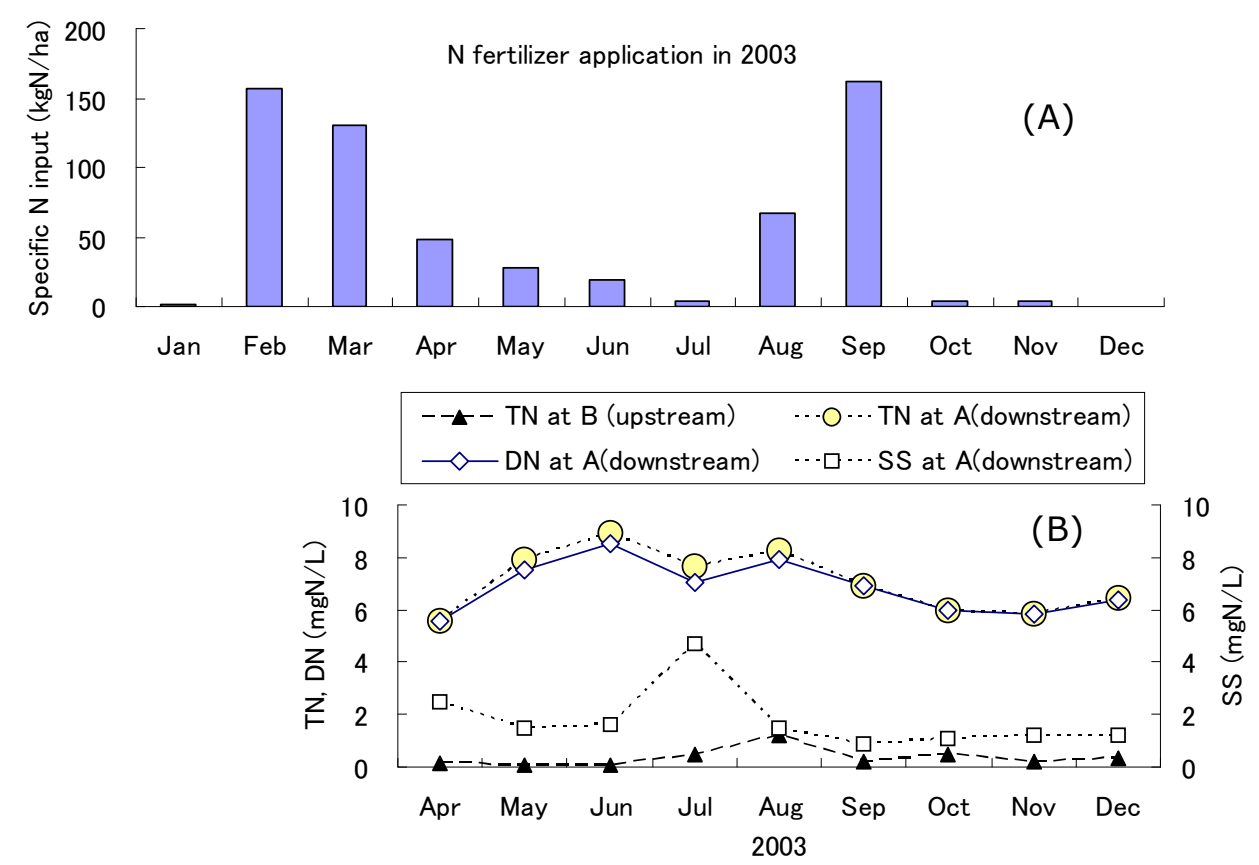

Fig. 2 - Temporal variation of nitrogen specific input as fertilizer to the tea plantation area (A) and TN, DN. SS concentrations in the river water at the sampling point $\mathrm{A}$, and $\mathrm{TN}$ at $\mathrm{B}(\mathrm{B})$ in 2003.
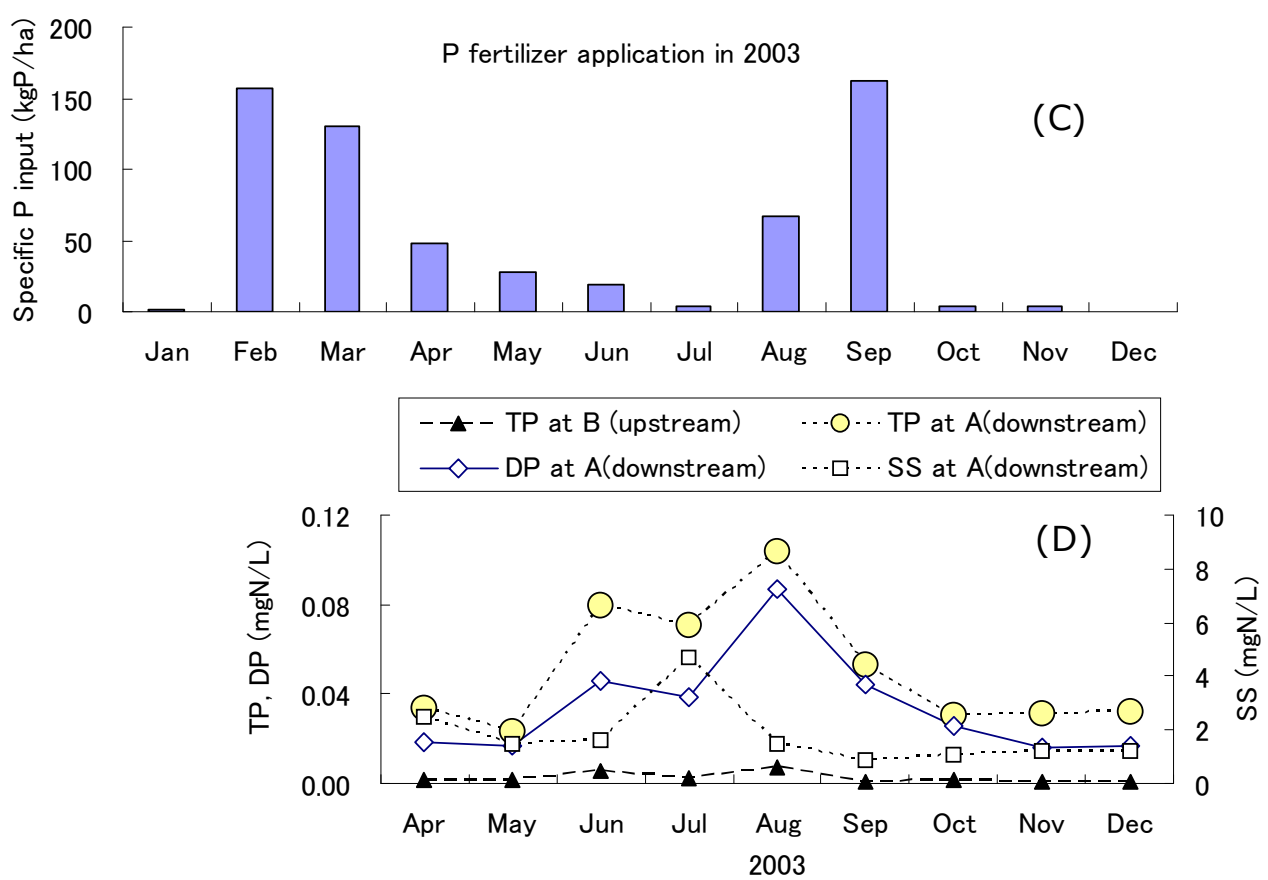

Fig. 3 - Temporal variation of phosphorus specific input to the tea plantation area as fertilizer (C) and TP, DP and SS concentrations in the river water at the sampling point $\mathrm{A}$, and TP at B (D) in 2003. 


\section{Temporal variations of nutrient concentrations during heavy storm}

Variations of water quality were influenced by storm discharge. Fig. 4 showed temporal variations of precipitation, flow rate, and nutrient concentrations, including SS, DN, PN, DP and PP during a large storm event on 9th October, 2004. The total rainfall in the storm period was $81.6 \mathrm{~mm}$. This was the 7 th largest in this year, and storm events in the year with more than $50 \mathrm{~mm}$ of total precipitation were observed 10 times. During the period, the decrease trend of DN concentrations was observed and it suggests that dissolved form of nitrogen was diluted by rainwater. The largest portion of $\mathrm{DN}$ in the period was nitrate nitrogen. On the other hand, the variation in concentrations of PN, PP, and DP depended on the rain intensity, which indicates that those components were discharged with the surface runoff of the tea plantation area.
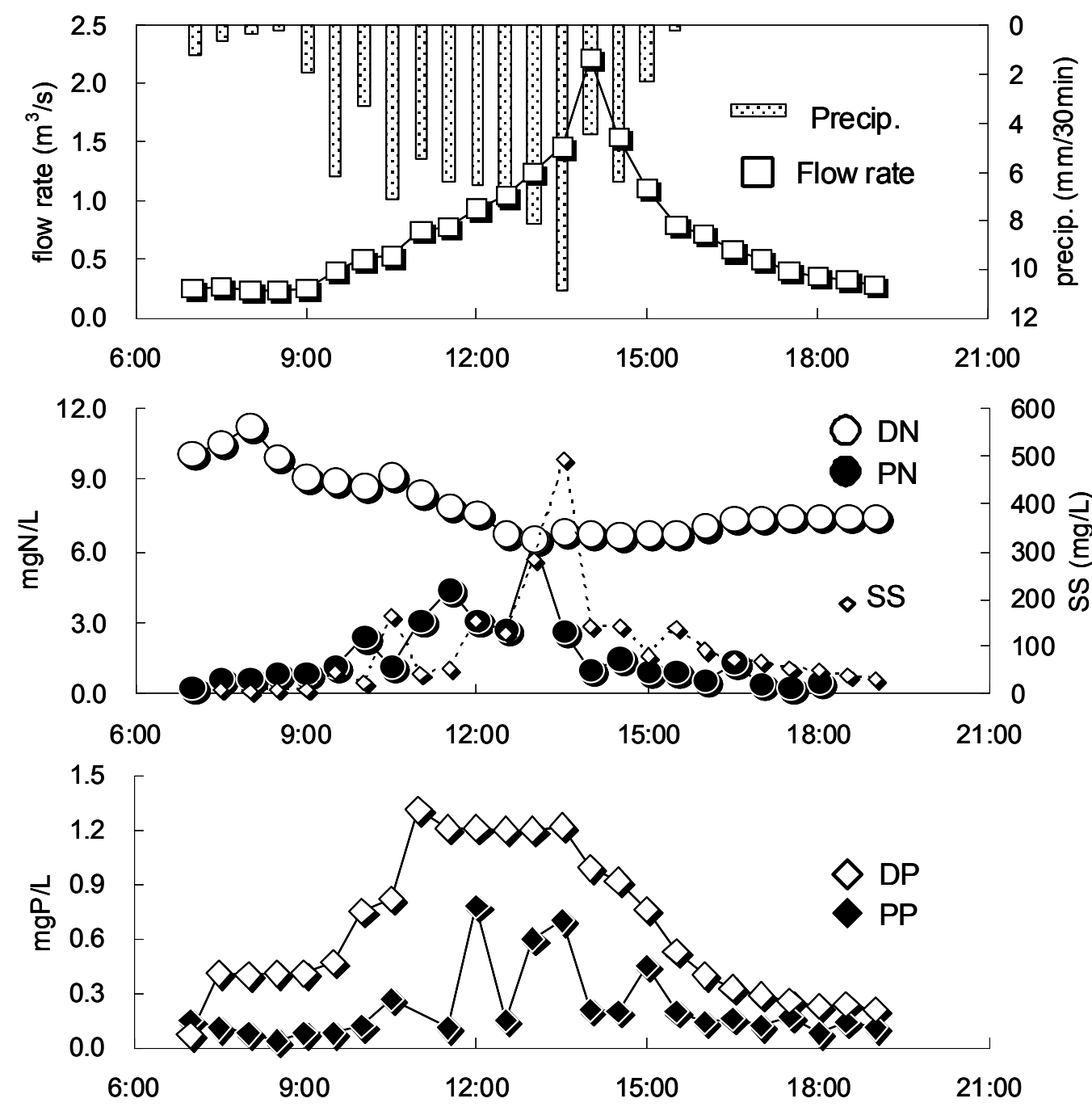

October 9th, 2004

Fig. 4 - Temporal variation of precipitation, flow rate, SS and nutrient concentrations, including DN, PN, DP and PP during the storm event on 9th October, 2004. 


\section{Relationships between nutrient loads and flow rate}

Relationships between the specific flow and the specific loads of components were examined by the following empirical equation;

$$
L=c Q^{n}
$$

where $L$ is the specific load of the component (concentration multiplied by flow per catchment area, $\mathrm{g} / \mathrm{s} / \mathrm{ha}$ ), $Q$ is the specific discharge (discharge per area, $\mathrm{m}^{3} / \mathrm{s} / \mathrm{ha}$ ), and $c$ and $n$ are constants. Runoff types are generally classified by the constant of $\mathrm{n}$ as washout type ( $n>1$, concentration increases with increase of flow), dilution type $(n<1$, concentration decreases with increase of flow) and stable type $(n=1$, concentration is roughly constant). Table 2 shows that runoff characteristic of total nitrogen in the studied watershed is classified as a dilution type, while those of total phosphorus is a washout type. The $\mathrm{n}$ value of particulate nitrogen was 1.9 , and $\mathrm{n}$ values of all form of phosphorus were between 1.4 and 1.82, indicating that these forms of nutrient were easily discharge during the storm. These characteristics are almost the same as those in the dry fields where vegetables are mainly grown (Yamada et al., 2004). The $\mathrm{n}$ value of DP was also more than 1. DP, mainly in phosphate form, might be largely retained in water in surface soil layer rather than groundwater in the deeper layer that can include high concentrations of nitrate. Contribution of the surface runoff to the river water would become significant during storm events, while the groundwater would be a major part of the river water in dry periods.
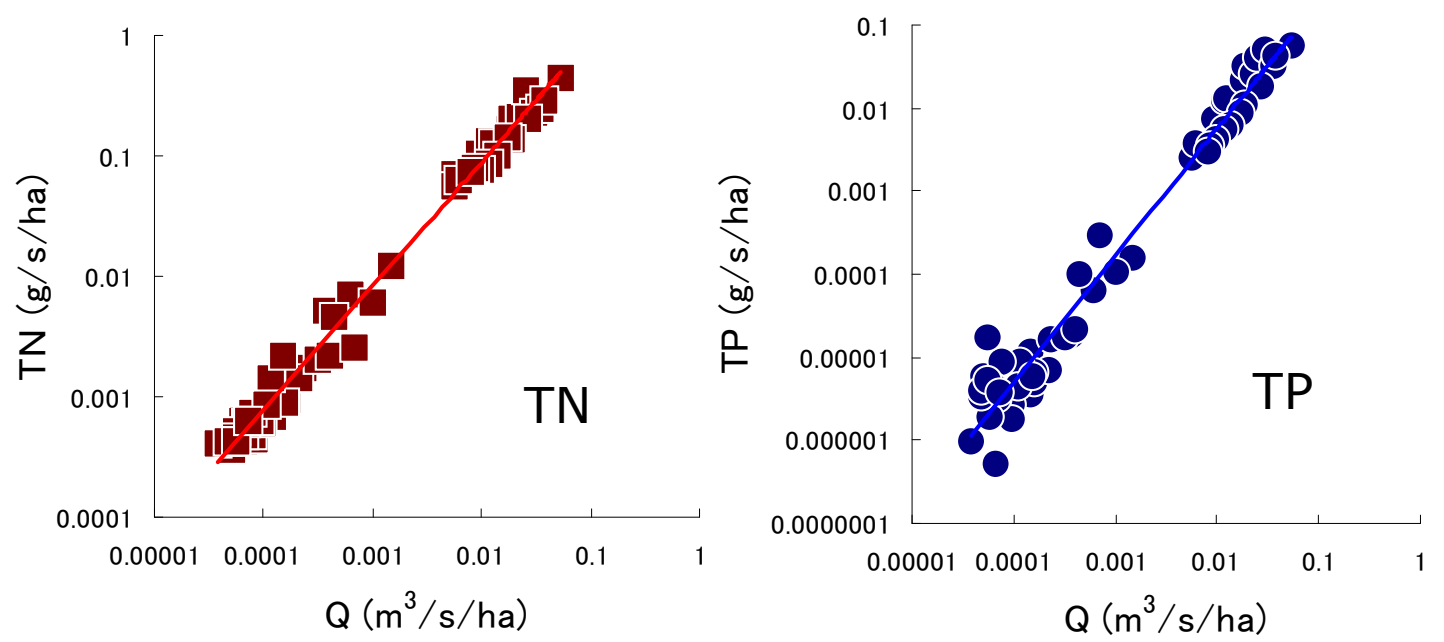

Fig. 5 - Relationships between specific discharge (Q) and specific loadings of TN and TP 
Table 2 - Values of the constants $n$ and the correlation of determination, $\mathrm{R}^{2}$ of the empirical equation of $L=c Q^{n}$.

\begin{tabular}{llllll}
\hline & $n$ & $\mathrm{R}^{2}$ & & $n$ & $\mathrm{R}^{2}$ \\
\hline $\mathrm{TN}$ & 0.90 & 0.92 & $\mathrm{TP}$ & 1.52 & 0.88 \\
\hline $\mathrm{DN}$ & 0.83 & 0.94 & $\mathrm{DP}$ & 1.40 & 0.84 \\
\hline $\mathrm{PN}$ & 1.90 & 0.72 & $\mathrm{PP}$ & 1.82 & 0.78 \\
\hline $\mathrm{NO}_{3}{ }^{-}-\mathrm{N}$ & 0.79 & 0.94 & $\mathrm{PO}_{4}{ }^{3-}-\mathrm{P}$ & 1.54 & 0.80 \\
\hline
\end{tabular}

\section{Estimation of annual nutrient budget in the tea plantation field in 2005}

Major inputs of nutrient into the studied area were application of fertilizer and precipitation. Using the annual total precipitation amount $(1227 \mathrm{~mm} /$ year) and the concentrations of nutrients in rain water $(0.07 \mathrm{mgN} / \mathrm{L}$ for $\mathrm{TN}, 0.049 \mathrm{mgP} / \mathrm{L}$ for TP) taken by bulk sampling during a heavy storm event in October 2004, annual nutrient input in 2005 was roughly estimated to $0.8 \mathrm{kgN} / \mathrm{ha} /$ year and $0.05 \mathrm{kgP} / \mathrm{ha} /$ year. But these values seem to be much lower than reported before $(10.6 \mathrm{kgN} / \mathrm{ha} /$ year and $0.3 \mathrm{kgP} /$ ha/year $)$ in the same region. These estimated inputs may be underestimated, partially because the annual precipitation in 2005 was lower than usual and the nutrient concentrations in rainwater were also low in this area.

Major input loadings of nutrients, fertilizer application in the area were calculated by the results of questionnaire survey to the farmer. There were 20 farmers in the 4 ha of studied area, and 15 farmers returned the questionnaire. The answer data covered $90 \%$ of the area. As results, $620 \mathrm{~kg} / \mathrm{ha} /$ year of nitrogen and $55 \mathrm{~kg} / \mathrm{ha} /$ year of phosphorus were applied in 2005. The nitrogen input was almost same as the guideline values recommended by the local agricultural institutes, which is $600 \mathrm{~kg} / \mathrm{ha} /$ year, while the phosphorus input was almost half of the value, $110 \mathrm{~kg} / \mathrm{ha} / \mathrm{year}$. The application timing was almost same among the farmers.

The empirical equations of $\mathrm{TN}$ and $\mathrm{TP}$ obtained by the relationships between the loadings in the former chapter and the flow rates were used for the estimation of the loadings from the tea plantation areas in 2005. The flow rate data were calculated with 10-minute interval monitoring of water levels at the sampling point and an $\mathrm{H}-\mathrm{Q}$ equation derived from the results of flow measurement at the site in 2005. With the L-Q equations, flow rates were converted into nutrient loadings at sampling point $A$, the watershed of which includes the tea plantation area as well as forest area upstream. Because the L-Q equation was based on the results of surveys in 2003 and in 2005 without winter time and that of the only a survey during a storm event in 2004, the calculated loadings should be assumed to be approximate values. The estimated annual nitrogen and phosphorus loadings at A were $2445 \mathrm{kgN} /$ year and $96 \mathrm{kgP} /$ year, respectively. Because of lack of flow rate at the upstream water sampling point, the loadings from forest area was estimated by the mean concentrations of nutrients in the upstream water $(0.78 \mathrm{mgN} / \mathrm{L}$ for $\mathrm{TN}$ and $0.003 \mathrm{mgP} / \mathrm{L}$ for TP) multiplied by the estimated annual water discharge derived from area proportion of the forest in the watershed (4.5ha for tea to 35.9ha for forest) since the nutrients concentrations at sampling point B were relatively 
stable. As a result, the annual discharge of nitrogen and phosphorus from the tea plantation area were estimated to be $535 \mathrm{kgN} / \mathrm{ha} /$ year and $21 \mathrm{kgP} / \mathrm{ha} /$ year, respectively, indicating that the tea plantation area has the significant impact on the environment downstream.

Table 3 shows estimated annual budget of nitrogen and phosphorus in the tea plantation area based on the results of the surveys. Since it was unable to estimate the annual crop yield based on the result of the questionnaire survey because of the lack of data, the average yield in this area was used $(74 \mathrm{kgN} / \mathrm{ha} /$ year for nitrogen and $5.3 \mathrm{kgP} / \mathrm{ha} /$ year for phosphorus). Only $12 \%$ of the nitrogen input was recovered as harvest. It was estimated that $86 \%$ of the nitrogen input was discharged into the river water. This ratio is much larger than the values by previous studies (Hasegawa et al., 1985, Takeda et al., 2002), or almost same as the value in a report (Yamamoto et al., 2005). The large amount of nitrogen loss could be caused by the groundwater in the area highly contaminated by nitrogen as nitrate. The result can also suggest that appropriate management of fertilizer application may result in significant reduction of nitrogen fertilizer amount without any influence on the crop yields. As for phosphorus, relatively small ratio of the discharged amount was estimated and only about $10 \%$ of the input was recovered as harvest, indicating that phosphorus in fertilizer can be accumulated in the area. The empirical equation model for the phosphorus loading shown in Table 2 suggests that there be a possibility that a large amount of phosphorus loadings be produced by high flow rate caused by a heavy storm.

Table 3 - Estimated annual budget of nutrients in the tea plantation field.

\begin{tabular}{llrr} 
& & $\begin{array}{c}\text { Nitrogen } \\
\mathrm{kg} / \mathrm{ha}\end{array}$ & $\begin{array}{r}\text { Phosphorus } \\
\mathrm{kg} / \mathrm{ha}\end{array}$ \\
\hline $\begin{array}{l}\text { Nutrient input to the tea } \\
\text { plantation area }\end{array}$ & Fertilizer & 620 & 55 \\
\hline $\begin{array}{l}\text { Nutrient output from the } \\
\text { tea plantation area }\end{array}$ & Rainfall & 0.8 & 0.05 \\
\hline \multirow{2}{*}{ Others (difference) } & $\begin{array}{l}\text { Discharge } \\
\text { to the river water }\end{array}$ & 74 & 5.3 \\
& $\begin{array}{l}\text { Denitrification, } \\
\text { discharge into groundwater, } \\
\text { other losses }\end{array}$ & 12 & 21 \\
\hline
\end{tabular}

\section{CONCLUSIONS}

A survey on nutrient losses in the river running through tea fields in central Japan was carried out in from 2003 to 2005 to clarify the impact of the fertilizer application in a small watershed including the tea plantation area on the river water quality and to estimate annual budgets of nitrogen and phosphorus in the area. The results of this study were the following:

1. The average concentrations of nitrate and phosphate in the stream water through the tea field were $8.09 \mathrm{mgN} / \mathrm{L}$ and $0.065 \mathrm{mgP} / \mathrm{L}$ respectively, which were more than 10 times 
higher than those in the upstream water which run through the forest.

2. It is suggested that water quality in the tea plantation area might not affect directly and immediately by fertilizer application, but the large amount of nutrients applied to the tea field could run off according to water discharge.

3. The runoff characteristics of nitrogen and phosphorus in the area were a dilution type and a washout type, respectively. The $n$ value of particulate nitrogen was 1.9 and that of all forms of phosphorus were between 1.4 and 1.82, indicating that these forms of nutrient can easily discharge during a storm event.

4. According to the questionnaire to the farmers in the studied area, $620 \mathrm{~kg} / \mathrm{ha} /$ year of nitrogen and $55 \mathrm{~kg} / \mathrm{ha} /$ year of phosphorus were applied to the tea plantation in a year. It was estimated that $86 \%$ of the nitrogen fertilizer was discharged into the river water, while $38 \%$ as for the phosphorus.

\section{Acknowledgement}

For the support of this study, we would like to thank Dr. Yukio Katayama, Ms. Kana Ichimi, Ms. Chinatsu Takeuchi, and Mr. Riichi Morisaki.

\section{REFERENCES}

Ebise S., Inoue T. and Numabe A. (1993). Runoff characteristics and observation methods of pesticides and nutrients in rural rivers. Water Science and Technology, 28(3-5), 589-593.

Hasegawa K., Okumura S., Kobayashi M. and Nakamura M. (1985). The changes of nitrogen flux for decreasing of the annual amount of fertilizer for a tea field. Bulletin of the Shiga Prefectural Agricultural Center, 26, 34-41. (in Japanese)

Matsuo H., Baba Y., Nakamura Y., Tokunaga T., Kitamori S., Hirata T. and Nishikawa M. (2000). The changes of nitrogen flux for decreasing of the annual amount of fertilizer for a tea field. Annual Report of the Fukuoka Institute of Health and Environmental Sciences, 27, 54-59. (in Japanese)

Nakasone H. and Yamamoto T. (2003). How much does diffuse pollution affect an aquatic ecosystem? Proc. of Diffuse Pollution Conference Dublin, 125-129.

Shiratani E., Yoshinaga I., Feng Y. W. and Hitomi T. (2004). Economic variation of nitrogen removal/load of cultivated land by a new replacement cost method. Journal of Japan Society on Water Environment, 27(7), 491-494. (in Japanese)

Takeda I., Kunimatsu T., Kihara Y. and Mori Y. (2002). Estimation of runoff pollutants of nitrogen, phosphorus and COD from a small catchment of tea field. Journal of Japan Society on Water Environment, 25(9), 565-570. (in Japanese)

Yamamoto T., Nakasone H., Matsusawa Y., Kuroda H. and Kato T. (2005). Continuous measurement of nitrogen runoff loads during long term and nitrogen balance in a tea field zone, Journal of Japan Society on Water Environment, 28(1), 43-48. (in Japanese)

Yamada T. and Inoue T. (2004). A study on runoff of phosphorus from agricultural areas in Japan, Proc. of 8th International Conference on Diffuse Pollution, 667-674. 